\title{
Neutrophil Pool Sizes and Granulocyte Colony-Stimulating Factor Production in Human Mid-Trimester Fetuses
}

\author{
ROBIN K. OHLS, YAN LI, ALY ABDEL-MAGEED, GEORGE BUCHANAN, JR., LISA MANDELL, \\ AND ROBERT D. CHRISTENSEN \\ Divisions of Neonatology and Hematology/Oncology, Department of Pediatrics, University of Florida \\ College of Medicine, and the Gainesville Women's Health Center, Gainesville, Florida 32610-0296
}

\begin{abstract}
We quantified neutrophils and neutrophil progenitors, and assessed granulocyte colony-stimulating factor (G-CSF) production in the liver and bone marrow of 20 human abortuses after elective pregnancy termination between 14 and 24 wk of gestation. Mature neutrophils were not observed in any of the liver specimens, but were present in the bone marrow as early as 14 wk. The concentrations of neutrophils in the fetal marrow were extremely low, by comparison with term infants and adults, with less than $5 \%$ of the nucleated cells being segmented neutrophils, band neutrophils, or metamyelocytes compared with $31-69 \%$ in term infants. Despite the low neutrophil populations, progenitors which had the capacity for clonal maturation into neutrophils in vitro were abundant in the fetal liver and fetal bone marrow. In addition, such progenitors had a dose-response relationship to recombinant G-CSF similar to that of progenitors from the bone marrow of healthy adults. At each gestational age tested, stimulation of mononuclear cells from fetal liver with IL- $1 \alpha$ generated less G-CSF protein and fewer G-CSF mRNA transcripts than did stimulation of mononuclear cells from fetal bone marrow. Mononuclear cells from the fetal bone marrow produced less G-CSF protein and mRNA than did mononuclear cells from the blood of
\end{abstract}

adults. Thus, the liver of the mid-trimester human fetus is almost devoid of neutrophils, and the bone marrow contains a significantly lower proportion of neutrophils than does the marrow of term neonates or adults. These findings correlate with IL- $1 \alpha$ induced production of G-CSF in these organs. The lack of G-CSF production might explain the small neutrophil reserves found in extremely preterm infants. (Pediatr Res 37: 806-811, 1995)

Abbreviations
NSP, neutrophil storage pool
G-CSF, granulocyte colony-stimulating factor
GM-CSF, granulocyte-macrophage colony-stimulating factor
CFU-MIX, colony-forming unit-mixed (multipotent
hematopoietic progenitor)
CFU-GM, colony-forming unit-granulocyte-macrophage
progenitor
BFU-E, burst forming unit-erythroid (primitive erythroid
progenitor)
$\alpha$-MEM, $\alpha$-modified minimal essential medium
r, recombinant

The NSP is the sum of all segmented neutrophils, band neutrophils, and metamyelocytes held in reserve for ready release into the circulation (1). Rat pups delivered prematurely have a much smaller NSP, per g of body weight, than do those delivered at term, and pups delivered at term have a smaller NSP than do adult rats (2-6). It is unknown, however, whether this observation applies to humans. Studies employing cells

\section{Received July 29, 1994; accepted January 3, 1995.}

Correspondence: Robin K. Ohls, M.D., Division of Neonatology, Department of Pediatrics, University of New Mexico School of Medicine, Albuquerque, NM 871315311.

Supported by grants HL-44951 and HD-00988 from the National Institutes of Health, grant 2960378 from the National Cancer Institute, a grant from The Children's Miracle Network, and grants from the Gainesville and Palm Beach, Florida, chapters of Stop! Children's Cancer.

Presented in part at the annual meeting of the Society for Pediatric Research, Seattle, WA, May 1994. from human umbilical cord blood suggest that preterm infants have a significant impairment in their capacity to produce the neutrophil growth factor, G-CSF $(7,8)$. Thus, if human preterm infants, like preterm rat pups, have a small NSP, this might be on the basis of their lack of G-CSF production. However, the significance of these umbilical cord blood studies is not clear. Specifically, it is more likely that cells within the hematopoietic organs play a much more significant role in producing hematopoietic growth factors than do cells in the umbilical cord blood; cord blood cells have been studied primarily because of the convenience of their acquisition. We maintained that additional studies were needed to determine the applicability of the animal and umbilical cord blood studies to human developmental biology. With this in mind, we obtained human fetuses ranging from 14 to $24 \mathrm{wk}$ of gestation, immediately after elective termination of pregnancies. From these we as- 
sessed the relative sizes of the neutrophil reserves and the capacity of the hematopoietic organs to generate G-CSF.

\section{METHODS}

Liver and marrow studies. Between July 1993 and March 1994, liver and bone marrow were obtained from 20 human abortuses ranging from 14 to $24 \mathrm{wk}$ gestation. Only fetuses that were normal by ultrasound examination and underwent elective pregnancy termination were studied. Pregnancy terminations were carried out by suction curettage (14-wk gestation) or by cervical dilatation and extraction curettage (15-24 wk gestation). In some of the abortuses only bone marrow was obtained, and in some only liver was obtained. Blood and bone marrow were also obtained from five healthy adult volunteers. The marrow was aspirated from the adult's anterior-superior iliac crest (after local Xylocaine infiltration) into a sterile syringe containing preservative-free heparin (SquibbMarsham, Cherry Hill, NJ). All of the studies were performed in accordance with protocols approved by the University of Florida Institutional Review Board, and informed consent was obtained from the donors of blood and marrow cells.

Cell suspensions. Suspensions of cells from the fetal livers were prepared by triturating the tissues in sterile $\alpha$-MEM (Hyclone Laboratories, Logan UT) and passing the pieces through serially smaller gauge needles, beginning with a \#16 and ending with a \#23. Fetal bone marrow cell suspensions were prepared by flushing the femurs and tibias three times with $5 \mathrm{~mL}$ sterile $\alpha$-MEM. Nucleated cell counts were performed electronically on the cell suspensions (Coulter Electronics, Hialeah, FL). Differential cell counts (500-1000 cells) were performed on Wright-stained films.

Flow cytometric analysis. Single cell suspensions were prepared in medium 199 (Life Technologies, Inc., Besthesda, MD). Dual staining was performed using phycoerythrinstained goat anti-mouse Ig secondary antibodies (Becton Dickinson Immunocytometry Systems, San Jose, CA) and FITCstained primary antibodies directed against mature myeloid/ monocyte cells. Samples were analyzed using primary MAb against CD14 and CD15 (kindly provided by Edward Ball, M.D., through Meadrex, West Lebanon, NH). Flow cytometry was performed with an Epics Profile Analyzer (Coulter Electronics).

Quantification of hematopoietic progenitors. Clonogenic assays were performed to assess fetal liver and marrow concentrations of multipotent hematopoietic progenitors (CFUMIX), primitive erythroid progenitors (BFU-E), and granulocyte-macrophage progenitors (CFU-GM). Assays were performed in methyl cellulose cultures containing $5 \mathrm{U} / \mathrm{mL}$ erythropoietin (Amgen, Thousand Oaks, CA) and $10 \mathrm{ng} / \mathrm{mL}$ each of G-CSF (Amgen), GM-CSF (Immunex Corp, Seattle, WA), IL-3 (R\&D Systems, Minneapolis, MN), and M-CSF (R\&D Systems). Whole cell suspensions (not fractionated) from fetal liver and fetal bone marrow were cultured at a density of $1-5 \times 10^{3} / \mathrm{mL}$ in $\alpha$-MEM containing $5 \times 10^{-4}$ mol/L $\beta$-mercaptoethanol (Eastman Kodak Co., Rochester, NY), 30\% FCS (Hyclone), 1\% BSA (Sigma Chemical Co., St. Louis, MO), and $1.1 \%$ methyl cellulose (Sigma Chemical Co.).
After $14 \mathrm{~d}$, colonies were evaluated in situ using an inverted microscope. All studies were performed in quadruplicate. To determine the varieties of cells present in the clones, the dishes were scraped, and their contents were rinsed three times, after which the cells rinsed from the dishes were smeared on glass slides and stained with Wright stain for 500 cell differential counts.

Response of granulocytic progenitors to rG-CSF. The effect of rG-CSF on production of neutrophils by progenitors was tested by plating light-density (specific gravity $<1.077$, Ficoll-Paque, Pharmacia Biotech Inc., Uppsala, Sweden) cell suspensions $\left(5 \times 10^{3}\right.$ cells $\left./ \mathrm{mL}\right)$ from fetal liver or adult marrow in methylcellulose cultures with $10 \mathrm{ng} / \mathrm{mL}$ recombinant stem cell factor (Amgen) and either $0,0.01,0.1,1,0$, or 10 or $100 \mathrm{ng} / \mathrm{mL}$ rG-CSF. After $10-12 \mathrm{~d}$ in culture, colonies were counted, and the cells were scraped from the plates and collected in $5 \mathrm{~mL} \alpha$-MEM. The nucleated cells present in each culture plate were then determined by hemocytometer counting of the cell suspensions. The neutrophils per plate were determined by multiplying the percentage of neutrophils from Wright-stained differential cell counts by the nucleated cells per plate.

Quantification of $G$-CSF. To assess the ability of fetal liver and bone marrow to generate G-CSF, $10^{6}$ light-density mononuclear cells from fetal liver, fetal marrow, or for comparison, mononuclear cells from the blood of five adults were incubated for $24 \mathrm{~h} \mathrm{in} 1 \mathrm{~mL} \alpha$-MEM in $5 \% \mathrm{CO}_{2}$ at $37^{\circ} \mathrm{C}$ with or without the addition of $10 \mathrm{ng} / \mathrm{mL}$ recombinant IL- $1 \alpha$ (R\&D Systems), an effective stimulator of mononuclear cells used in previous studies $(7,8)$. All studies were performed in quadruplicate. The purified rIL- $1 \alpha$ had a specific activity of $>5 \times 10^{8} \mathrm{U} / \mathrm{mg}$ and a purity of $>95 \%$ by SDS-polyacrylimade gel electrophoresis. Concentrations of G-CSF in the supernatants were measured by ELISA (R\&D Systems). The minimal G-CSF concentration detectable was $11 \mathrm{pg} / \mathrm{mL}$. The ELISA recognized both natural and recombinant G-CSF and had no cross-reactivity with the following cytokines: IL-1 $\alpha$, IL-1 $\beta$, IL-2, IL-3, IL-4, IL-5, IL-6, tissue necrosis factors $\alpha$ and $\beta$, GM-CSF, transforming growth factor $\beta 1$, and platelet-derived growth factor.

RNA isolation and Northern blot analysis. RNA was prepared from light density mononuclear cells obtained from fetal liver, fetal bone marrow, and from adult blood, after such cells were cultured for $24 \mathrm{~h}$ in the presence or absence of IL- $1 \alpha(10$ $\mathrm{ng} / \mathrm{mL}$ ). A guanidinium extraction buffer was added to the cells, and RNA was isolated using the method described by Chomczynski and Sacchi (9). The RNA was subjected to electrophoresis through a $1 \%$ agarose-formaldehyde gel, transferred to a biotrace nylon membrane (Gelman Sciences, Ann Arbor, MI), and immobilized by UV cross-linking (10). The human G-CSF probe (kindly supplied by Dr. Steve Gillis, Immunex Corp., Seattle, WA) was labeled, hybridized to the blot, washed, and subjected to autoradiography. A human $\beta$-actin probe was used as a control (University of Utah core nucleotide synthesis laboratory).

Statistical analysis. Specimens were grouped for analysis by gestational age as follows: $14-17 \mathrm{wk}, 18-20 \mathrm{wk}$, and $21-24$ wk. The Wilcoxon signed ranks test was used to assess differences in cell populations at the different gestational ages and 
between liver and bone marrow. Differences in concentrations of G-CSF in cell suspensions between control and IL-1stimulated cells were assessed by a paired $t$ test. Differences in concentrations of G-CSF in cell suspensions between different groups were assessed by a nonpaired $t$ test. A two-tailed $p$ value of less than 0.05 was considered to indicate a significant difference.

\section{RESULTS}

Differential cell counts of fetal liver and fetal bone marrow. The differential counts of the fetal liver cell suspensions are shown in Table 1. At 14-17 wk no neutrophils were observed in the liver. At $18-20$ wk a small number of promyelocytes, but no postmitotic neutrophils, were observed. At 21-24 wk the percentage of promyelocytes and myelocytes had increased, but no postmitotic neutrophils were observed, and total neutrophils were less than $2 \%$ of the total nucleated cells.

Differential counts of the fetal bone marrow cell suspensions are shown in Table 2. At all gestational ages studied the marrow and liver populations were very different from one another. The bone marrow invariably contained a much smaller proportion of normoblasts than did the liver, and segmented neutrophils were evident within the fetal bone marrow as early as 14 wk. Compared with term neonates and adults, however, the percentages of cells in the fetal marrow categorized as NSP cells were very low. Thirty one to $69 \%$ of the nucleated cells in the marrow of term neonates and $25-50 \%$ in the marrow of adults are NSP cells $(11,12)$ whereas less than 5 percent of the cells in the fetal bone marrow were NSP cells.

In four specimens less than $20 \mathrm{wk}$ of gestation, the relative lack of neutrophils in fetal liver and marrow was validated by flow cytometry. Specifically, less than $1 \%$ of the liver cells were positive for CD14 or CD15, while $2.6 \%$ of the marrow cells were CD14 positive, and $8.5 \%$ were CD15 positive.
Granulocyte progenitors in the fetal liver and bone marrow. Fetal liver contained a higher concentration of CFU-MIX and BFU-E than did fetal bone marrow (Table 3). Although the fetal liver cell suspensions contained no postmitotic neutrophils (Table 1), CFU-GM were indeed present. In fact, the concentration of CFU-GM in fetal liver was not significantly less than in fetal bone marrow. It was not clear from these studies, however, whether the CFU-GM in fetal liver had matured in vitro into neutrophil/macrophage clones or, rather, into macrophage clones only. Therefore the cells were washed from the culture dishes, smeared on glass slides, and stained for differential cell counts. Of the total cells developing from fetal liver progenitors, $5.5 \pm 1.8 \%$ were promyelocytes and myelocytes, and $5.6 \pm 1.1 \%$ were postmitotic neutrophils.

The rG-CSF dose-response relationship of light density cell suspensions (containing progenitors and accessory cells) from fetal liver and adult bone marrow is shown in Figure 1. At every concentration of $\mathrm{rG}$-CSF tested, progenitors from fetal liver produced more neutrophils per plate than did progenitors from adult marrow.

G-CSF production by fetal liver and marrow. After a $24-\mathrm{h}$ incubation with IL- $1 \alpha$, the supernatants of fetal liver cells contained a greater concentration of G-CSF than did liver cells after incubation without IL-1 $\alpha$ (Fig. 2, upper panel). At all of the three gestational ranges tested, fetal bone marrow (Fig. 2, lower panel) generated more G-CSF than did fetal liver. Liver cells of fetuses $<18$ wk produced more G-CSF than liver cells of fetuses $\geq 18$ wk $(1857 \pm 1623$ versus $165 \pm 156, p=0.05)$. Neither fetal liver nor fetal marrow generated as much G-CSF as did monocytes from the blood of healthy adults. Similarly, fewer G-CSF mRNA transcripts were present in cells of fetal liver than fetal marrow, and adult blood cells contained greater G-CSF mRNA transcripts than did fetal liver (Fig. 3).

Table 1. Differential counts, in percentages (mean and $95 \%$ confidence intervals) of liver cell suspensions from elective abortions at 14-24-wk gestation

\begin{tabular}{|c|c|c|c|}
\hline \multirow[b]{2}{*}{ Cells } & \multicolumn{3}{|c|}{ Gestation (wk) } \\
\hline & $14-17(n=5)$ & $18-20(n=7)$ & $21-24(n=8)$ \\
\hline \multicolumn{4}{|l|}{ Normoblasts } \\
\hline Pronormoblast & $3.1(1.7-4.5)$ & $3.4(2.8-4.0)$ & $2.9(1.1-4.7)$ \\
\hline Basophilic N & $18.4(10.8-26.0)$ & $13.6(12.0-15.2)$ & $13.7(9.0-18.4)$ \\
\hline Polychromatophilic $\mathrm{N}$ & $57.5(44.6-69.8)$ & $55.3(48.0-63.0)$ & $51.1(45.6-56.6)$ \\
\hline Orthochromic $\mathrm{N}$ & $13.9(8.7-19.1)$ & $15.9(12.2-19.5)$ & $14.2(9.2-19.2)$ \\
\hline Total erythroid & $92.9(86.6-99.2)$ & $87.8(83.0-92.6)$ & $81.9(76.9-86.9)$ \\
\hline \multicolumn{4}{|l|}{ Neutrophil } \\
\hline Promyelocyte & $0(0-0)$ & $0.2(0.0-0.4)^{*}$ & $1.2(0.8-1.6)^{*} \dagger$ \\
\hline Myelocyte & $0(0-0)$ & $0(0-0)$ & $0.2(0.0-0.4)^{*}+$ \\
\hline Metamyelocyte & $0(0-0)$ & $0(0-0)$ & $0(0-0)$ \\
\hline Band & $0(0-0)$ & $0(0-0)$ & $0(0-0)$ \\
\hline Segmented & $0(0-0)$ & $0(0-0)$ & $0(0-0)$ \\
\hline Total neutrophils & $0(0-0)$ & $0.2(0.0-0.4)^{*}$ & $1.4(0.9-1.9)^{*} \dagger$ \\
\hline Undifferentiated blast & $0.5(0.0-1.1)$ & $3.1(1.3-4.9)^{*}$ & $2.2(1.6-3.0)^{*}$ \\
\hline Macrophage & $0.5(0.1-1.2)$ & $1.2(0.8-1.6)$ & $1.3(0.9-1.9)$ \\
\hline Lymphocyte & $5.4(2.6-7.8)$ & $3.9(0.3-7.5)$ & $11.3(9.1-17.5)^{*}+$ \\
\hline Eosinophil & $0(0-0)$ & $0(0-0)$ & $0(0-0)$ \\
\hline Other & $0.7(0.0-1.5)$ & $3.4(1.0-5.8)$ & $1.9(0.0-4.7)$ \\
\hline
\end{tabular}

$\mathrm{N}=$ normoblast; other $=$ hepatocyte, megakaryocyte, or cell of undetermined origin.

$* p<0.05$ vs $14-17$ wk.

$\dagger p<0.05$ vs $18-20$ wk. 
Table 2. Differential counts, in percentages (mean and 95\% confidence intervals) of bone marrow cell suspensions from elective abortions at 14-24-wk gestation

\begin{tabular}{|c|c|c|c|}
\hline \multirow[b]{2}{*}{ Cells } & \multicolumn{3}{|c|}{ Gestation (wk) } \\
\hline & $14-17(n=6)$ & $18-20(n=6)$ & $21-24(n=8)$ \\
\hline \multicolumn{4}{|l|}{ Normoblasts } \\
\hline Pronormoblast & $0.3(0.1-0.5)^{*}$ & $1.1(0.7-1.5)^{*}$ & $0.5(0.3-0.7)^{*}$ \\
\hline Basophilic N & $1.4(0.8-2.0)^{*}$ & $3.1(2.3-3.9)^{*}$ & $1.7(0.7-2.7)^{*}$ \\
\hline Polychromatophilic N & $9.2(4.2-14.2)^{*}$ & $12.9(6.7-19.1)^{*}$ & $12.3(7.1-17.5)^{*}$ \\
\hline Orthochromic N & $12.1(1.5-23.7)$ & $20.7(8.5-32.9)$ & $8.1(3.7-12.5)$ \\
\hline Total erythroid & $23.0(9.7-36.3)^{*}$ & $37.8(21.0-54.6)^{*}$ & $22.6(13.6-31.6)^{*}$ \\
\hline \multicolumn{4}{|l|}{ Neutrophils } \\
\hline Promyelocyte & $5.9(2.6-8.4)^{*}$ & $5.8(3.2-8.4)^{*}$ & $5.0(3.8-7.2)^{*}$ \\
\hline Myelocyte & $2.7(1.1-3.9)^{*}$ & $3.4(1.8-5.0)^{*}$ & $2.1(1.1-3.1)^{*}$ \\
\hline Metamyelocyte & $2.1(1.1-3.1)^{*}$ & $2.5(0.7-4.3)^{*}$ & $1.7(0.7-2.7)^{*}$ \\
\hline Band & $3.1(1.3-4.9)^{*}$ & $3.2(0.6-6.0)^{*}$ & $1.6(0.4-2.8)^{*}$ \\
\hline Segmented & $1.2(0-2.6)^{*}$ & $1.1(0-2.5)^{*}$ & $0.4(0.2-0.6)^{*}$ \\
\hline Total neutrophils & $13.8(8.0-19.6)^{*}$ & $16.1(8.1-24.1)^{*}$ & $10.7(5.7-15.7)^{*}$ \\
\hline Undifferentiated blast & $8.9(2.7-15.1)^{*}$ & $11.4(6.0-16.8)^{*}$ & $11.6(8.0-15.2)^{*}$ \\
\hline Macrophage & $5.4(1.6-9.2)^{*}$ & $4.2(1.8-6.6)^{*}$ & $3.1(1.5-4.7)$ \\
\hline Lymphocyte & $35.3(19.5-51.1)^{*}$ & $28.8(20.8-36.8)^{*}$ & $50.3(43.5-57.1)^{*}$ \\
\hline Eosinophil & $0.5(0-1.1)$ & $1.1(0-2.3)$ & $1.2(0.4-2.0)^{*}$ \\
\hline Other & $0.8(0.4-1.2)$ & $0.5(0.1-0.9)$ & $0.4(0.2-0.6)$ \\
\hline
\end{tabular}

$\mathrm{N}=$ normoblast; other = megakaryocyte, or cell of undetermined origin.

$* p<0.05$ vs fetal liver.

Table 3. Hematopoietic colonies (mean \pm SEM) per $5 \times 10^{3}$ plated cells, quantified $14 d$ after plating nucleated cell suspensions (nonfractionated) from fetal liver or fetal bone marrow

\begin{tabular}{lccc}
\hline \multicolumn{1}{c}{ Cells } & CFU-MIX & BFU-E & CFU-GM \\
\hline Liver $(n=7)$ & $12.7 \pm 2.1$ & $20.7 \pm 3.1$ & $22.3 \pm 4.5$ \\
Marrow $(n=6)$ & $6.7 \pm 1.4^{*}$ & $9.3 \pm 2.7^{*}$ & $33.1 \pm 7.2$ \\
\hline
\end{tabular}

Cells were cultured in methylcellulose in the presence of recombinant erythropoietin, rG-CSF, rGM-CSF, rIL-3, and rM-CSF.

$* p<0.05$ vs liver.

\section{DISCUSSION}

During pyogenic infections in otherwise normal adults, the daily neutrophil utilization rate increases up to 8-fold over steady-state utilization (13-15). Despite this increased demand for neutrophils, the NSP (composed of 5-7 $\times 10^{9}$ segmented neutrophils, band neutrophils, and metamyelocytes per $\mathrm{kg}$ of body weight) rarely becomes completely depleted $(1,13,15$, 16). In prematurely delivered neonates, however, complete depletion of the NSP is a relatively common sequelae of bacterial infection, frequently accompanied by profound neutropenia, overwhelming sepsis, and death $(2,3,17-21)$.

The propensity of preterm infants to deplete their NSP during bacterial infection has been ascribed, in part, to qualitative and quantitative developmental deficiencies of neutrophils and their progenitors (22-24). Substantial evidence exists regarding poor chemotaxis, decreased bacterial killing, and diminished oxidative metabolism of neutrophils from human preterm infants. The notion of a deficient NSP in preterm infants, however, has been inferred solely from animal models. For instance, in a previous study we observed that newborn rats had only $25 \%$ of the NSP, per g body weight, of adult rats (2). We also observed that the quantity of CFU-GM per g body weight in newborn rats was only about $10 \%$ that of adult rats (4). In this study, granulocytic progenitors were indeed present in human fetal liver and marrow, excluding the hypothesis that

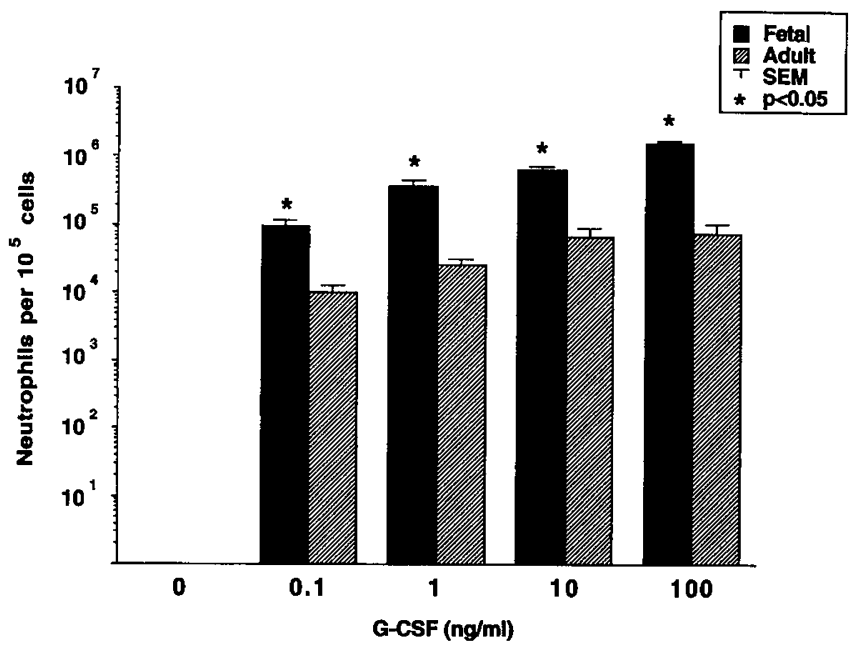

Figure 1. Neutrophils washed from culture dishes $10-12 \mathrm{~d}$ after plating $5 \times$ $10^{3}$ light density cells from fetal liver or adult bone marrow. Cells were cultured in the presence of recombinant stem cell factor $(10 \mathrm{ng} / \mathrm{mL})$ plus various concentrations of rG-CSF. Neutrophil counts are listed per $10^{5}$ cells plated.

the lack of granulocytopoiesis in the fetal liver was the result of lack of CFU-GM in that organ. Fetal liver contained a higher concentration of CFU-MIX and BFU-E than did fetal bone marrow, which likely forms the basis for the erythropoietic nature of mid- trimester fetal liver documented in this study.

Little information is available regarding granulocytopoiesis in the human fetus (25-27), and available data are not sufficient to judge whether the NSP of mid-trimester human fetuses is small, as is the case in rats. In the present study we observed no neutrophils beyond the myelocyte stage in the livers of any of 20 human fetuses at 14-24-wk gestation. Although neutrophils were observed in the bone marrow, even as early as 14 wk of gestation, the NSP invariably constituted less than $5 \%$ of the nucleated marrow cells. This is in marked contrast to the 


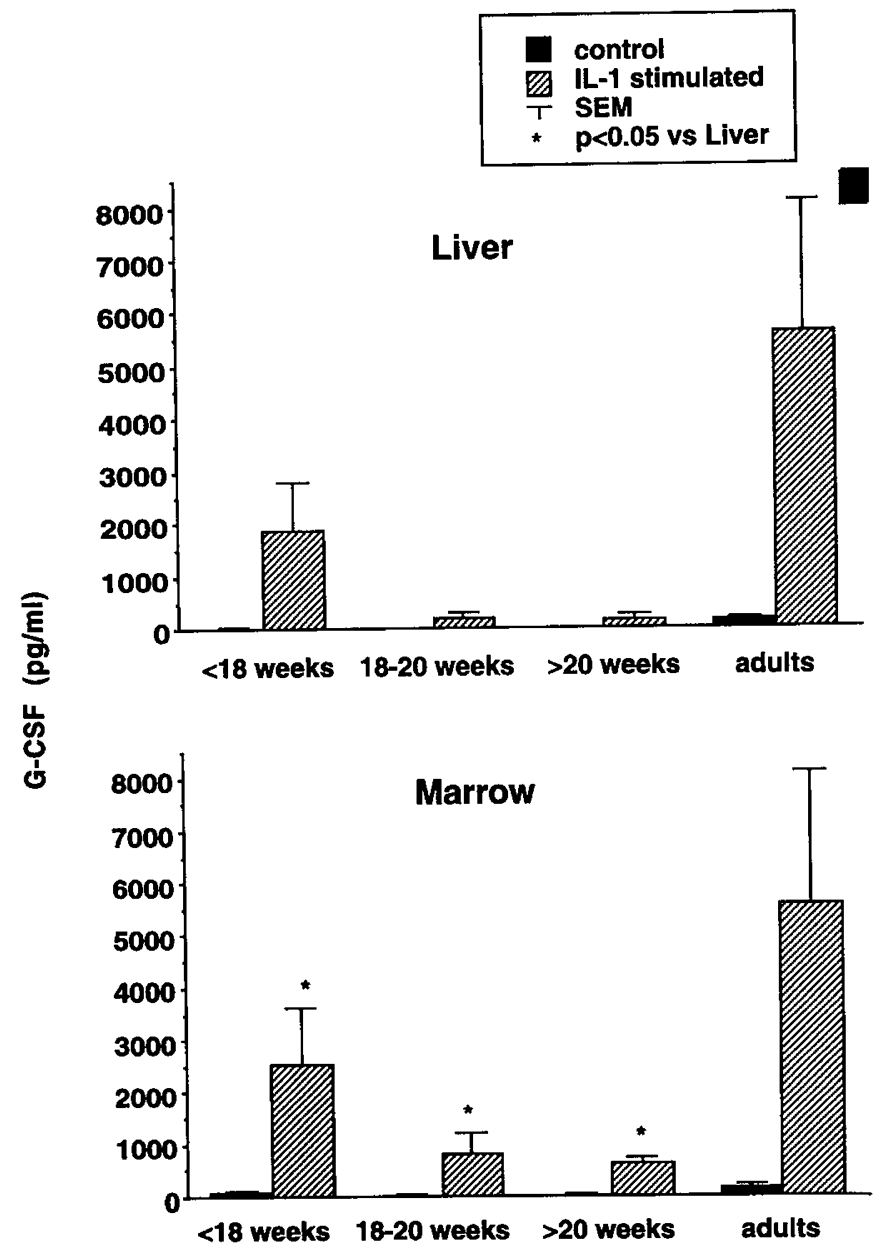

Figure 2. Accumulation of G-CSF in $1-\mathrm{mL}$ culture dishes containing $10^{6}$ mononuclear cells obtained from fetal liver $v s$ adult blood (upper panel), and obtained from fetal bone marrow $v s$ adult blood (lower panel). Cells were cultured for $24 \mathrm{~h}$ with or without IL-1 $\alpha(10 \mathrm{ng} / \mathrm{mL})$.

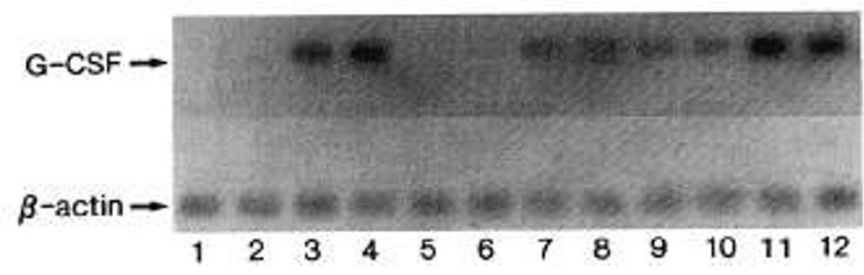

Figure 3. Northern analysis of G-CSF mRNA accumulation in cells of fetal or adult origin, incubated for $24 \mathrm{~h}$ with or without IL- $1 \alpha(10 \mathrm{ng} / \mathrm{mL}) . \beta$-actin bands for each sample are shown as a control in the lower section of the blot. Lanes 1 and 2, two separate samples of fetal marrow incubated without IL- $1 \alpha$; lanes 3 and 4 , fetal marrow samples incubated with IL- $1 \alpha$; lanes 5 and 6 , two separate samples of fetal liver incubated without IL- $1 \alpha$; lanes 7 and 8 : fetal liver samples incubated with IL- $1 \alpha$; lanes 9 and 10 , two separate adult samples incubated without IL- $1 \alpha$; lanes 11 and 12 , adult samples incubated with IL- $1 \alpha$.

31-69\% NSP cells observed in marrow aspirates of term infants (11), and the 25-52 percent NSP cells observed in the marrow of adults (12). In the present studies, we made no attempt to sum the NSP from all bones, liver, and spleen, as would be required to calculate the absolute NSP per $\mathrm{kg}$ of body weight. Although the possibility that a quantitative difference in absolute numbers of granulocyte progenitors still exists, the complete absence of mature neutrophils from the liver and their very small percentages in the femurs and tibias lead us to conclude that, indeed, human fetuses up to $24 \mathrm{wk}$ of gestation have an extremely small NSP.

The size of the NSP is determined not only by the absolute quantity of granulocyte progenitors, but also by the growth factors that stimulate and regulate granulocyte development. Previous studies by Cairo et al. (7) illustrated that mononuclear cells obtained from the umbilical cord blood of term infants produce G-CSF poorly, compared with mononuclear cells obtained from the blood of adults. We previously observed that cells from the umbilical cord blood of preterm infants produce G-CSF less well than do those of term infants (8). Although elevated levels of G-CSF and GM-CSF have been reported in the cord blood of normal term infants $(28,29)$, the source of growth factor production was not evaluated.

The physiologic relevance of these observations can be questioned, however, because cells within the hematopoietic organs are probably of much greater significance in hematopoietic regulation than are blood cells. We interpret our present observations as validating the conclusions of the previous cord blood studies. It is now clear that when stimulated with the inflammatory cytokine IL- $1 \alpha$, fetal bone marrow, fetal liver, and fetal blood all generate lower concentrations of G-CSF, and G-CSF mRNA, than do cells of adults.

The physiologic role of G-CSF includes up-regulation of neutrophil function and neutrophil production $(30,31)$. This appears to be the case for cells of the neonate as well as for adults (32). Perhaps the deficiencies in neutrophil function in preterm neonates, as well as the small NSP, can be explained, at least in part, by lack of G-CSF. Since the fetus exists in utero in a sterile environment, it may not be advantageous, during the first or second trimester of pregnancy, to produce G-CSF. However, when delivery occurs prematurely, perhaps the preterm neonate's limitation in producing G-CSF becomes a disadvantage, but one that could theoretically be remedied pharmacologically. In support of that potential approach, our present studies indicate that neutrophil progenitors are present in the fetal liver and bone marrow, and that these progenitors are responsive to $\mathrm{rG}-\mathrm{CSF}$.

Acknowledgments. The authors thank Shannon Koza for performing the FACs analyses, and Patricia Lassiter for her help in obtaining the fetal tissue.

\section{REFERENCES}

1. Cartwright GE, Athens JW, Wintrobe MM 1964 The kinetics of granulopoiesis in normal man. Blood 24:780-803

2. Erdman SH, Christensen RD, Bradley PP, Rothstein G 1982 Supply and release of storage neutrophils: a developmental study. Biol Neonate 41:132-137

3. Zeligs BJ, Armstrong CD, Walser JB, Bellanti JA 1982 Age-dependent susceptibility of neonatal rats to group B streptococcal type III infection: correlation of severity of infection and response of myeloid pools. Infect Immun 37:255-263

4. Christensen RD, Rothstein G 1984 Pre- and postnatal development of granulocytic stem cells in the rat. Pediatr Res 18:599-602

5. Christensen RD, Macfarlane JL, Taylor NL, Hill HR, Rothstein G 1982 Blood and marrow neutrophils during experimental group B streptococcal infection: quantification of stem cell, proliferative, storage, and circulating pools. Pediatr Res 16:549553

6. Christensen RD 1988 Developmental changes in pluripotent hematopoietic progenitors (CFU-GEMM). Early Hum Dev 16:195-205 
7. Cairo M, Suen Y, Knoppel E, Dana R, Park L, Clark S, van de Ven D, Sender L 1992 Decreased G-CSF and IL-3 production and gene expression from mononuclear cells of newborn infants. Pediatr Res 31:574-578

8. Schibler KR, Liechty KW, White WL, Christensen RD 1993 Production of granulocyte colony-stimulating factor in vitro monocytes from preterm and term neonates. Blood 82:2269-2289

9. Chomczynski P, Sacchi N 1987 Single-step method of RNA isolation by acid guanidinium thiocyanate-phenol-chloroform extraction. Anal Biochem 162:156-159

10. Sambrook J, Fritsch EF, Maniatis T 1989 Molecular Cloning: A Laboratory Manual. Cold Spring Harbor Laboratory, Cold Spring Harbor, NY

11. Rosse C, Kraemer MJ, Dillon TL, McFarland R, Smith NJ 1977 Bone marrow cell populations of normal infants: the predominance of lymphocytes. J Lab Clin Med 89:1225-1240

12. Kjeldsberg C 1993 Normal blood and bone marrow values in man. In: Lee, RG, Bithell TD, Forester J, Athens JW, Lukens JN (eds) Wintrobe's Clinical Hematology, Vol 9. Lea \& Febiger, Philadelphia, p 2303

13. Marsh JC, Boggs DR, Cartwright GE, Wintrobe MM 1967 Neutrophil kinetics in acute infection. J Clin Invest 46:1943-1953

14. Athens JW, Haab OP, Raab SO, Boggs DR, Ashenbrucker H, Cartwright GE, Wintrobe MM 1965 Leukokinetic studies. XI. Blood granulocyte kinetics in polycythemia vera, infection, and myelofibrosis. J Clin Invest 44:778-788

15. Athens JW, Haab OP, Raab SO, Mauer AM, Ashenbrucker H, Cartwright GE, Wintrobe MM 1961 Leukokinetic studies. IV. The total blood, circulating and marginal granulocyte pools and the granulocyte turnover rate in normal subjects. J Clin Invest 40:989-995

16. Athens JW 1993 Granulocytes-neutrophils. In: Lee, RG, Bithell TD, Forester J, Athens JW, Lukens JN (eds) Wintrobe's Clinical Hematology, Vol. 9. Lea \& Febiger, Philadelphia, pp 339-246

17. Christensen RD, Bradley RR, Rothstein G 1981 The leukocyte left shift in clinical and experimental neonatal sepsis. J Pediatr 98:101-105

18. Liechty KW, Schibler KR, Ohls RK, Perkins SL, Christensen RD 1993 The failure of newborn mice infected with Escherichia coli to accelerate neutrophil production correlates with their failure to increase transcripts for granulocyte-colony-stimulating factor and interleukin-6. Biol Neonate 64:331-340

19. Christensen RD, Rothstein G 1980 Exhaustion of mature marrow neutrophils in neonates with sepsis. J Pediatr 96:316-318
20. Wheeler JG 1984 Neutrophil storage pool depletion in septic, neutropenic neonates. Pediatr Infect Dis 3:407-409

21. Cairo MS, Worcester C, Ruker R, Hanten S, Amlie R, Sender L, Hicks D 1992 Randomized trial of granulocyte transfusions versus intravenous immune globulin therapy for neonatal neutropenia and sepsis. J Pediatr 120:281-285

22. Cairo MS 1993 Therapeutic implications for dysregulated colony-stimulating facto expression in neonates. Blood 82:2269-2272

23. Hill HR 1987 Biochemical, structural, and functional abnormalities of polymorphonuclear leukocytes in the neonate. Pediatr Res 22:375-382

24. Wilson C 1986 Immunologic basis for increased susceptibility of the neonate to infection. J Pediatr 108:1-12

25. Kelemen E, Janossa M 1980 Macrophages are the first differentiated blood cells formed in human embryonic liver. Exp Hematol 8:996-1000

26. Carbonell F, Calvo W, Fliedner TM 1982 Cellular composition of human fetal bone marrow. Acta Anat 113:371-375

27. Forestier F, Daffos F 1985 Hematological values of 163 normal fetuses between 18 and 30 wk of gestation. Pediatr Res 20:342-346

28. Bailie KEM, Irvine AE, Bridges JM, McClure B 1994 Granulocyte and granulocytemacrophage colony-stimulating factors in cord and maternal serum at delivery. Pediatr Res 35:164-168

29. Laver J, Duncan E, Abboud M, et al. 1990 High levels of granulocyte and granulocyte-macrophage colony-stimulating factors in cord blood of normal full-term neonates. J Pediatr 116:627-632

30. Souza LM, Boone TC, Gabrilove, J, Lai PH, Zsebo KM, Murdock DC, Chazin VR, Bruszewski J, Lu H, Chen KK, Barendt J, Platzer E, Moore MAS, Mertelsmann R, Welte K 1986 Recombinant human granulocyte colony-stimulating factor; Effects on normal and leukemic myeloid cells. Science 232:61-65

31. Welte K, Bonilla MA, Gillio AP, Boone TC, Potter GK, Gabrilove JL, Moore MAS, O'Reilly RJ, Souza LM 1987 Recombinant human granulocyte colony-stimulating factor: effects on hematopoiesis in normal and cyclophosphamide-treated primates. $J$ Exp Med 165:941-948

32. Gessler P, Kirchmann N, Kientsch-Engel K, Hass N, Lasch P, Kachel W 1993 Serum concentrations of granulocyte colony-stimulating factor in healthy term and preterm neonates and in those with various diseases including bacterial infections. Blood $82: 3177-3182$ 